\title{
Book Review: Wulf, A. (2015). The Invention of Nature. The Adventures of Alexander von Humboldt. The Lost Hero of Science. John Murray Publishers
}

Dan Manolescu (Corresponding author)

Freelance ESL Instructor and Award-Winning Author, New York, USA

Email: dan.manolescu@att.net

Received: $11 / 03 / 2021$

Accepted: 27/05/2021

Published: 01/07/2021

Volume: 2 Issue: 4

How to cite this paper: Manolescu, D. (2021). Book Review: Wulf, A. (2015). The Invention of Nature. The Adventures of Alexander von Humboldt. The Lost Hero of Science. John Murray Publishers. Journal of Practical Studies in Education, 2(4), 1-4 DOI: https://doi.org/10.46809/jpse.v2i4.26

Copyright (C) by author(s) and Global Talent Academy Ltd. This work is licensed under the Creative Commons Attribution International License (CC BY 4.0).

http://creativecommons.org/licenses/by/4.0/

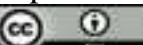

Andrea Wulf, the author of this magnificent book, was born in India, but spent some years in Germany before moving to England, where she currently resides. For the research done in preparation for this huge project that culminated with the publication of The Invention of Nature, the author has been highly praised in the literary and obviously the scientific world. For the thrilling journey through the years in search of Alexander von Humboldt's right place among other scientists and discoverers, the avid reader will be in for a unique, geographical, and highly informative trip of a lifetime. Organized in five parts, with a prologue and an epilogue, this biography/adventure story also contains maps, drawings, illustrations, a note on Humboldt's publications, as well as colorful pictures of various places Humboldt visited during his explorations.

As stated in the book, Alexander von Humboldt is said to have created a new concept about nature and some researchers even argue he also invented the way we see nature today. Andrea Wulf's widely acclaimed book The Invention of Nature has already been picked as a Book of the Year fifteen times by A. N. Wilson in the Evening Standard and Mark Cocker in The Spectator; by The Economist, New Scientist, Sunday Times, Independent, Daily Telegraph, Nature, Brain Pickings, Atlantic, Jezebel, The New York Times, Washington Post and Australian. The current edition is also The 2015 Costa Biography Award Winner and The 2017 Science Book Prize Winner.

What better way to familiarize yourself with Humboldt's achievements than to look in amazement at all the places that bear his name: Kap Humboldt and Humboldt Glacier in Greenland, rivers and waterfalls in Tasmania and New Zealand, Rue Alexandre de Humboldt in Paris, The Humboldt Redwoods State Park in California, Humboldt Parks in Chicago and Buffalo, to name just a few? Close to 300 plants and more than 100 animals are named after him. Several minerals carry his name from Humboldtit to Humboldtin, and there is an area on the moon called 'Mare Humboldtianum.' Many German-speaking schools across Latin America hold biannual athletic competitions called Juegos Humboldt - Humboldt Games. (p. 7)

Born the same year as Napoleon Bonaparte (1769), Alexander von Humboldt did not show too much interest in books, but instead enjoyed the outdoors, wandering through the countryside, looking at plants, animals, and everything else that he could examine and draw. His family nicknamed him 'the little apothecary' because he was seen regularly coming back home with his pockets full of insects and plants. "According to his family lore, one day the Prussian king, Frederick the Great, asked the boy if he planned to conquer the world like his namesake, Alexander the Great. Young Humboldt's answer was: 'Yes, Sir, but with my head."' (p. 14)

A short visit to England, Netherlands, and France was young Alexander's first glimpse of other places and other 
countries. In London, he was introduced to "botanists, explorers, artists, and thinkers.” (p. 19) Captain William Bligh (of the Mutiny on the Bounty) and Joseph Banks, Cook's botanist on his first voyage around the world, were among the many people Alexander managed to meet, and the whole atmosphere around him signaled an unquenched thirst for discovery. 'There is a drive in me,' he wrote, 'that often makes me feel as if I'm losing my head.' (p. 19)

Right after finishing his studies, when he was around twenty-one, he followed his mother's advice and enrolled in the Mining Academy in Freiberg, where he completed in eight months a study program that took others three years. (p. 20) Upon graduation, he was made a mining inspector at the young age of twenty-two, a position that gave him a chance to travel to places in Brandenburg, Silesia, and Poland. Shortly afterwards, he visited Johann Wolfgang Goethe, Germany's greatest poet, who was also a scientist, and who wrote an essay that attracted Humboldt's attention: Metamorphosis of Plants, in which he touted the idea that "there was an archetypal, or primordial, form underlying the world of plants" (p. 29), a concept that will reverberate in the scientific realm in the years to come.

The author traces the explorer's adventures starting from June 1799, when Humboldt and his friend Aimé Bonpland left Spain on board of the frigate Pizarro to embark on a historical voyage whose real purpose was to discover how "all forces of nature are interlaced and interwoven." (p. 45). The first place in the New World that greeted them with luscious green palms and banana groves was New Andalusia, today part of Venezuela. What he saw provided his first observations regarding the balance in nature, which he duly noted when he argued that "Everything is interaction and reciprocal." (p. 59) To his amazement, the young explorer also noticed that a monkey they saved in the jungle seemed to "distinguish engravings that showed its favorite foods - such as the insects - while pictures of human and mammal skeletons didn't interest [it] at all." (p. 67)

In 1804, after five years of successful discoveries, Humboldt found himself in Cuba and then on the East Coast of the United States, where President Jefferson invited him to Washington, D.C. Over the next few days, they met several times, and Humboldt found his hero "living with the simplicity of a philosopher." (p. 101) The exchange of information was beneficial to both of them because Humboldt shared maps of his own design that Jefferson needed about the disputed border between Mexico and the United States. In his turn, the American President, a progressive farmer who experimented with crop rotation, presented his views about politics. The author says that Jefferson even argued that only farmers should be elected as congressmen because he regarded them as "the true representatives of the great American interest." (p. 106)

Back in Europe, Humboldt settled down for a short while in Paris, a place he found to be teeming with knowledgeable citizens, and where science was a top priority. He was welcomed by naturalists Georges Cuvier and Jean-Baptiste Lamarck and met twenty-one-year-old Simon Bolivar, who would eventually become the leader of the revolutions in South America. (p. 117) On his way to Berlin, via Lake Como in northern Italy, Humboldt stopped to meet Alessandro Volta, the Italian scientist who had just invented the electric battery. (p. 124) Soon afterwards, King Friedrich Wilhelm III was very happy to see the Prussian back in Germany and offered him a yearly pension of 2,500 thalers with no strings attached. While in Berlin, Humboldt managed to finish and publish Essay on the Geography of Plants, the first volume in what eventually became the thirty-four-volume Voyage to the Equinoctial Regions of the New Continent. The essay, published in French and German, gave him a chance to include the drawing of his so-called Naturgemälde - "the visualization of the idea he had conceived in South America, of nature made up of connections and unity." (p. 126) In an honest acknowledgement of the concept of nature and imagination being closely interwoven, Humboldt dedicated the Essay on the Geography of Plants to Goethe, whose influence was quite obvious and highly appreciated.

When things did not go as planned, for various reasons, but mostly because Humboldt did not feel at home in his motherland, he turned to writing and produced Views of Nature, in itself a completely new genre, a bestseller that was later on published in eleven languages:

In Views of Nature Humboldt conjured up the quiet solitude of Andean mountaintops and the fertility of the rainforest, as well as the magic of a meteor shower and the gruesome spectacle of catching the electric eels in the Llanos. He wrote of the 'glowing womb of the earth' and 'bejeweled' riverbanks. Here a desert became a 'sea of sands,' leaves unfolded 'to greet the rising sun,' and apes filled the jungle with 'melancholy howlings.' In the mists at the rapids of the Orinoco, rainbows danced in a game of hide-and-seek - 'optical magic,' as he called it. (p. 132)

One year after returning to France, Humboldt worked very hard to complete the first installment of Vues des Cordillères et monuments des peuples indigènes de l'Amérique, which included, among other things, sixty-nine engravings of Chimborazo, volcanoes, Aztec manuscripts and Mexican calendars. To celebrate Latin America's natural world and its unique culture, the following notes were added when Humboldt sent the book to Goethe in 1810: 'Nature and art are closely united in my work.' (p. 135)

Following Humboldt's quest for knowledge that could not be gained from books alone - as Humboldt very well knew the author surmises that a scientist had to be in nature, which is exactly what this geographical pilgrimage is all about: a deeply engaging combination of scientific exploration and highly enjoyable reading of facts and ideas about nature.

Upon his return to London, Humboldt discovered he needed permission from the Spanish king to travel to South America, and on top of this, the directors of the East India Company seemed quite reluctant to give him their approval. While in London, though, he did not waste his time; instead, he attended meetings at the Royal Society that had been founded in the $1660 \mathrm{~s}$ 'for the improvement of natural knowledge by Experiment,' where scientists debated and exchanged opinions freely about telescopes, comets, botany, and fossils. 'All scholars are brothers,' said Humboldt after one meeting. (p. 166) He had good reasons to feel happy: His books were selling well in England: The Political Essay of New Spain (1811) was followed 
by Personal Narrative - a travelogue for the general population, the first of seven volumes had been translated in 1814 . (p. 167)

As luck would have it, after fourteen years in Europe, Friedrich Wilhelm III granted Humboldt the necessary funds so he could take his Naturgemälde across the globe. After he bought books and the necessary instruments for the voyage, he planned to travel to Constantinople, to Mount Ararat, across Persia to Bandar Abbas, and then all the way to India. Having taken lessons in Persian and Arabic while in Paris proved to be extremely useful. Living in the French capital, Humboldt prepared for the next chapter of his explorations. Before his voyage to India, Humboldt worked on his books and did not forget that the full results from his Latin American trip had not been published. All in all, the books would eventually become the thirty-four-volume Voyage to the Equinoctial Regions of the New Continent, and it comprised Personal Narrative plus specialized books on botany, zoology, and astronomy. (p. 173) Shortly afterwards, in 1817, Humboldt wrote another essay: On the Isothermal Lines and the Distribution of Heat on the Earth, which was published in 1821 and visualized global climate patterns. (p. 177)

Soon after his return to Berlin, on November 3, 1827, Humboldt started a series of lectures at the university. Free of charge, the lectures attracted a wide audience of all social strata who were captivated by the presenter as well as the topics, ranging from poetry and astronomy to geology and landscape painting. The success of his lectures prompted him to organize a conference for the German Association of Naturalists and Physicians, whose purpose was not to talk to the scientists, but to let them talk to each other. This proved to be quite a revolutionary idea, and naturalists came from Cambridge, Zurich, Florence, and even from Russia. The event gave the attendees a chance to exchange and share knowledge, and most of them forged friendships which, in time, developed into networks on various levels of disciplines. (p. 196)

A well-deserved change came when Tsar Nicholas I invited Humboldt to visit Russia. Although the Siberian expedition was not exactly what the group of scientists had expected, the fifty-nine-year old Humboldt surely experienced moments of excitement along the road that stretched for miles east of Moscow. The destination was the Altai Mountains, and on the way, the natural beauty of the willow herb (Epilobium angustifolia), the delphiniums (Delphinium elatum, and the Maltese Cross (Lychnis chalcedonica) showed their splendor. Pressed plants, rocks, and samples of ores filled up their trunks and Humboldt was now ready to cross the Chinese-Mongolian border. The friendly exchange of greetings left a lasting impression, not only on Humboldt and his companions, but in equal share, on the local Mongolians. (p. 210) In 1829, after spending so many years traveling, Humboldt returned to Berlin. It was his last expedition, but his ideas had already spread around the world.

Charles Darwin was one of the many explorers who came under Humboldt's spell. During his last years at Cambridge, Darwin was fascinated by Personal Narrative, which he read out loud and recommended to his botany teacher, John Stevens Henslow, as well as to many other fellow scientists who felt exactly the same way about the grandiose descriptions in the book. During his Beagle voyage, Darwin developed a habit of writing his own notes, commenting on Humboldt's descriptions of the southern hemisphere, which he found to be 'sensational.' Humboldt and Darwin mingled scientific writing with poetic depictions of the natural habitat they so much loved and admired. They both "had the rare ability to focus in on the smallest detail - from a fleck of lichen to a tiny beetle - and then to pull back and out to examine global and comparative patterns." (p. 226) When anatomists and ornithologists analyzed the papers Darwin had brought back from his explorations, they were quick to realize that Darwin, like Humboldt, "recorded his emotional responses to nature, as well as providing scientific data and information about indigenous people." (p. 229) When the Voyage of the Beagle was published in 1839, Darwin sent a copy to Humboldt, who replied in a long letter, acknowledging that it was an 'excellent and admirable book.' Not only did Humboldt read every page - which made Darwin so happy that he said, 'Few things in my life have gratified me more,' - he also got somebody to translate it into German. (p. 230)

In 1834, the year the term scientist was coined, Humboldt began writing his most popular work: Cosmos. A Sketch of the Physical Description of the Universe, based on his Berlin lecture series, but embellished with new data he had accumulated during his trip to Russia. In writing his main opus, the explorer also resorted to additional resources from fellow scientists, classicists, historians, and geologists who were only happy to send him their lists of plants, maps, or manuscripts, which he obviously appreciated and gladly reviewed. The most important part of Cosmos (volume I published in 1845) was the introduction, in which Humboldt laid claim that Nature was a 'living whole' where organisms were bound together in a 'netlike intricate fabric.' (p. 245)

The public reaction to Cosmos was enthusiastic, to say the least. In France, Hector Berlioz called Humboldt a 'dazzling' writer, and, in England, Queen Victoria's husband, Prince Albert, requested a copy, while Darwin could hardly wait for the English translation. (p. 246) When the second volume appeared in 1947, the readers' reception was just the same, although his book was a little bit different, albeit just as informative and entertaining as the first volume.

The second volume of Cosmos was a history of 'poetic descriptions of nature' and landscape painting through the ages from the Greeks and Persians to modern literature and art. It was also a history of science, discovery and exploration, covering everything from Alexander the Great to the Arabic world, from Christopher Columbus to Isaac Newton. (p. 247)

The poetic aspect of Cosmos presented an unexpected appeal to literary giants as well. When Henry David Thoreau moved back to Concord, Massachusetts, young as he was, the natural beauty of his hometown and its surroundings played a major role in developing his taste for long walks, and eventually the countryside gave him a chance to mingle science and poetry and therefore produce his famous Walden. Humboldt's Cosmos was definitely an inspiration, and literary critics rightly called Walden David Thoreau's answer to Cosmos. 
Humboldt's fame spread quickly all over the world. The Great Exhibition in London displayed his portrait as did palaces as far as that of the King of Siam in Bangkok, and his birthday was celebrated in Hong Kong. An American journalist went as far as to say, "Ask any schoolboy who Humboldt is, and the answer will be given." The reception in North America flattered him but also embarrassed him. Towns, several counties, a river, bays, lakes, and mountains carried his name, as well as The Humboldt Times in Eureka, California, and a hotel in San Francisco. (p. 273)

In May of 1818, one year after his retirement from the presidency, James Madison delivered a speech at the Agricultural Society in Albemarle, Virginia, in which he applied Humboldt's observations from South America to the United States. Madison's speech reverberated of Humboldt's warnings about deforestation and other similar catastrophic effects which eventually paved the way for what is now called the American Environmentalism.

The image behind Humboldt's greatest achievements, unfortunately, has faded over the years. With so many explorers who followed in his footsteps, science has developed into a world venture, and his discoveries have become so popular that people are beginning to forget his name, which slowly disappeared, although his ideas have made science accessible and popular. When asked why people might be still interested in Humboldt, Andrea Wulf returned to the basic idea that there is a strong connection between knowledge, art, and poetry, between science and emotions that point to where she had started from: "Humboldt was driven by a sense of wonder for the natural world - a sense of wonder that might help us today realize that we only protect what we love." (p. 336)

\section{References}

Darwin, C. (2014). A Naturalist's Voyage Round the World: The Voyage of the Beagle. Skyhorse.

Goethe, J. W. von. (2009). The Metamorphosis of Plants. Cambridge, Massachusetts: The MIT Press.

Humboldt, A. von. (2019). Cosmos: A Sketch of a Physical Description of the Universe. Translated from the German by E. C. Otte. Hard Press Publishing. , (1821). On the Isothermal lines, and the Distribution of Heat over the Globe. Edinburgh: A. Constable.

, (1995). Personal Narrative of a Journey to the Equinoctial Regions of the New Continent. Abridged and Translated with an Introduction by Jason Wilson. Penguin Classics.

, (2011). Political Essay on the Island of Cuba. Edited by Vera M. Kutzinski and Ottmar Ette. Chicago: The University of Chicago Press.

, (2019). Political Essay on the Kingdom of New Spain, Volume 1. Translated by John Black. Chicago: The University of Chicago Press.

, (2019). Political Essay on the Kingdom of New Spain, Volume 2. Translated by John Black. Chicago: The University of Chicago Press.

, (2013). Views of the Cordilleras and Monuments of the Indigenous People of the Americas: A Critical Edition. Edited by Vera M. Kutzinski and Ottmar Ette. Chicago: The University of Chicago Press.

(2014). Views of Nature. Translated by Mark W. Person. Chicago and London: The University of Chicago Press.

Humboldt, A. von \& Bonpland, A. (2008). Essay on the Geography of Plants. Translated by Sylvie Romanowski. Chicago:

The University of Chicago Press.

Nordhoff, C. \& Hall, J. N. (1932). Mutiny on the Bounty. Boston: Little, Brown and Company.

Thoreau, H. D., (2012). Walden; or, Life in the Woods. Empire Books. 